\title{
A Qualitative Study of Female Academics: The Case Associate Senior Lecturers
}

\author{
Inés Lozano-Cabezas ${ }^{1} \&$ Marcos Jesús Iglesias-Martínez ${ }^{1}$ \\ ${ }^{1}$ Faculty of Education, University Institute for Gender Studies Research, University of Alicante, San Vicente del \\ Raspeig, Spain \\ Correspondence: Marcos Jesús Iglesias-Martínez, Faculty of Education, University Institute for Gender Studies \\ Research, University of Alicante, Ctra. San Vicente del Raspeig, s/n 03690 San Vicente del Raspeig, Spain. Tel: \\ 34-965-909-857.
}

Received: January 28, 2021

Accepted: March 5, 2021

Online Published: March 22, 2021

doi:10.20849/jed.v5i1.849

URL: https://doi.org/10.20849/jed.v5i1.849

\begin{abstract}
The equality of relations in the place of work is one of the most important keys for development teacher and professional at Universities. This paper reports a qualitative study of female academics' personal experiences of professional life, especially with regard to and problems of their integration in professional networks as departments and research teams. The results show that, although mentoring and learning networks are now an established part of the range of professional development opportunities for academic staff in general, these do not apply in the same way to female academics. Moreover, whilst female academics do not experience institutional discrimination, they are dissatisfied with opportunities for participation and career advancement. The results can contribute to a better design of the campus politics.
\end{abstract}

Keywords: higher education, female academic, professional development

\section{Introduction}

This research examines the extent to which the university provides its female academics with the opportunities, patterns and support for appropriate and equitable professional life. The study analyses at Spanish University the present-day situation of academic women through their own voices. In doing so, we are guided by the study of Cammack and Kalmbach-Phillips (2002), who has shown that staff narratives are an indispensable element to determine the concept and characteristics of female professional identity.

In Spanish universities there is a clear and persisting gender differential in favour of men. Although the number of women enrolled in university studies has increased (51\% by INNEBASE, 2020), the academic life process shows a substantial decline, particularly in the set of postdoctoral women. In brief, although the number of female students enrolled in higher education is greater than the number of male students, there is a progressive decline in the professional career development of women relative to men. These data are also consistent with distribution patterns on a national scale, which show a differential favourable to men (FECYT, 2017) also make evident that the presence of women in academic management and leadership roles - deans, heads of institutes or departments is very limited, especially in the top posts of centres, institutes and departments of science and technology. In the case of female academics, then, it is clear from the statistical data (European Commission, 2016) in many countries that customs, habits and practices characteristic of a community with a clearly masculine history and origin, continue to survive.

In the field of research, the gender indicators of scientific production show that men's participation in journal publication exceeds that of women (Aiston, \& Jung, 2015; Aiston \& Fo, 2020; Scharber, Pazurek \& Ouyang, 2017). For instance, according to data based on ISI-Thomson Scientific (2008), in published articles, "male participation makes up $90 \%$ of production" (p. 39). In the case of the research potential of papers authored only by men or only by women, shows a wide difference, favouring men, although these narrows when the authors are from both genders (King et al., 2017). Additionally, in reference to the accreditation and recognition of scientific activity in Spain by the national organisation Commission for Evaluation of Research Activity, the data show that the number of women who have obtained a positive research evaluation is significantly fewer than the number of men (INEBASE, 2020). The situation in national science research centres and in local ones is similar to that previously described. The pyramid shows $70 \%$ are women on the base line and only $9 \%$ at the vertex. 
Practically all data, in research, teaching, management, or other professional aspects of academic life, reveal gender inequalities. We must recognise that "historical discrimination" still continues despite legislative efforts and attempts to promote social awareness of parity. Over the last twenty years, this tendency has persisted. This pattern of discrimination means that the potential and talent of many women is still being wasted. On the international scene, several studies reveal similarities with the Spanish situation (Dapiton, Quiambao, \& Canlas, 2020; Gallardo, 2021; Santos, Horta \& Amâncio, 2020; Wieczorek-Szymańska, 2020). For instance, in Europe, academic women are a clear minority group (European Commission, 2016).

One of the most important American studies, the MIT report (Massachusetts Institute of Technology, 1999), has inspired extensive research into academics, especially in those areas in which the salary depends on scientific production. A wide range of gender studies includes studies and analyses of how politics and the economy influence equality, especially in Further Education in the European Union (Danowitz-Sagaria, 2007). Other studies based in North American universities point out the rare presence of top female academics in top posts (Krefting, 2003). Acker and Dillabough (2007) have analysed, in the Faculties of Education of the University of Ontario between the years 1960 and 1990, the way in which gender differentials have influenced the working life of female academics (Acker \& Armenti, 2004). Several studies carried out in the United Kingdom also consider that conditions are still a long way from being balanced and that the male organisational model still persists (Bagilhole \& Goode, 2001; Knights \& Richards, 2003; Ledwith \& Manfredi, 2000).

\subsection{General Trends in Professional Development in Universities}

There is general agreement among academics that the professional training should take place within the learning community (Boylan, Coldwell, Maxwell \& Jordan, 2018). The characterizing a model for lecturer education based on the conceptualization of learning as a process of decision-taking, compromise and negotiation (Lave \& Wenger, 1991). The view of teacher training taken emphasizes the idea that the knowledge acquired is interacts with that of all his or her peers within the teaching community (Cochran-Smtih \&Villegas, 2015). Collaborative participation, then, brings together and compares different interpretations, in order to construct knowledge within the community in which the lecturer (Gore \& Rosser, 2020; Raduan \& Na, 2020). Today's collaborative culture creates a richer, shared environment in which distances disappear and relationships are fomented.

Academic life is based on continuous development. Understanding career advancement as something purely promotional is a narrow concept of professional life. Professional life must be understood as an integrated concept that includes career advancement and professional development. Multiple factors influence the social context in which professional development takes place (Blickenstaff, 2005). Yet the evidence is that social and situational concepts of learning development, particularly those of the professional development of teachers (Jones, \& Brien, 2011), provide a sound basis for the design of professional development opportunities for academic staff. Lave and Wenger (1991) propose situating the learner and expert in a space with multiple paths of progress, in a network of dynamic and complex interactions. Cochran-Smith and Lytle (2009) emphasize, also, that the knowledge of learners does not only depend on their contact with external experts, but that it comes from reflection on their own experiences of practice and interaction with peers in collaborative settings. In short, both individual support through mentoring relationships allied with collaborative activity, at least in theory, enables reflection and self and peer confrontation (Day, 1993) which stimulates the building of a more collegial, shared knowledge base in the workplace. For example, whereas in the past it has been seen as essential in initial university education that a mentor should supervise the theory and practical work of the students of which he is tutor, this has not always been the case for new academics. Flores and Day (2006) argue that mentoring should have a stronger focus in the workplace; and that, in the long run, the opportunities that an institution gives to academic staff will contribute to the students' learning opportunities (Darling-Hammond, 2017) and it can work in favour of gender equity mentoring and leadership in higher education (Brabazon \& Schulz, 2020) . As a complement to this, social networks and participation in learning communities are now accepted as the intrinsic conditions required in order to avoid isolation, fears and insecurity and promote well-grounded professional development (Desimone \& Pak, 2017; Lieberman \& Pointer-Mace, 2008; Whitcomb, Borko \& Liston, 2009) and in particularly for women academics (Barnard, Rose, Dainty \& Hassan, 2021; Bosanquet, Mailey, Matthews \& Lodge, 2017). This research sought to find out the sources of this dissatisfaction through the eyes of female academics.

Erixon-Arreman and Weiner (2007), which show how male colleagues tend to concentrate more on knowledge and power relationships than women. The quality of relations in organisations in the place of work is one of the most important keys for learning and professional identification as it is in each daily situation where integration takes place and opportunities of learning are offered. As regards this, the study Gender differences at critical transitions in the careers of science, engineering and mathematics faculty (NAP, 2009) emphasizes how a lack of dialogue 
can reduce opportunities. "This distance may prevent women from accessing important information and may make them feel less included and more marginalized in their professional lives" (p.74).

This paper reports a qualitative study of female academics' personal experiences of professional life, especially with regard to and problems of their integration in professional networks as departments and research teams.

\section{Method}

\subsection{Research Narrative}

Research based on the voices of those participating has been called a narrative research path by Clandinin (2013) and Clandinin and Husu (2017). This methodology is based on the interpretation of personal accounts and metaphors of professional knowledge interwoven with the diversity of life histories and knowledge from their social and professional contexts (Goodson, Antikainen, Sikes \& Andrews, 2017). The analysis of biographical discourse about a person's career is, for Bourdieu (2000), the base for observing social structure, especially the relationship between gender and power (Wingood \& DiClemente, 2002). For these reasons, we chose to analyse the discourse of women academics as illustrating 'different ways of thinking' in different university life contexts (Anderson, Goodall \& Trahar, 2020).

\subsection{Participants}

Academic women who have taken part in this research come from all the faculties of the Spanish University. The number of academic women who participated was 20 Associate Senior lecturers. These teachers work part-time at the university, as their main work takes place in other professional contexts.

\subsection{Data Collection and Processing}

Qualitative methodology enables researchers to analyse and interpret subjects' answers within the framework of their social context (Bourdieu, 2000). The data were collected using an semi-interview model. In the interview, participants were asked to reflect on the three basic questions of our research, considering their personal experiences and professional career. All the audio recordings of the interviews were later transcribed as written texts.

The AQUAD 7 (Huber \& Gürtler, 2012) software was chosen due to its capacity to integrate the emergent qualitative categories from the statements given by the participants, with the aims, conceptual framework and structure that researchers should apply during the processes of interpretation and codification (Miles, Huberman \& Saldaña, 2014). This allows categories and codes that emerge from the participants voices the structuring of the lines that the research conceptual framework establish. To increase the trustworthiness of the interpretation, three experts validated the process until a definitive interpretation was agreed.

To collect our data we decided on an semi-interview model as this is most frequently employed in studies of a qualitative nature (Denzin \& Lincoln, 2000). The interview is one of the most commonly-used ways of approaching lecturers' practical epistemology. In the interview, subjects were asked to reflect on their opportunities for participation and career advancement. The average duration of the interviews was between 30 and 60 minutes. All the audio recordings of the interviews were later transcribed as written texts.

The semi-structured interviews focused upon three research questions:

1. Do academic women have or have they had a mentor? And have they perceived gender differences in their mentoring relation?

2. Have academic women perceived differences in their professional opportunities, access to promotion, departmental integration within the workplace and in the distribution of formal managerial and leadership responsibilities?

3. How do they perceive relations with colleagues in terms of opportunities for professional and career development?

\section{Results}

\subsection{First Research Question: The Experience of Having a Mentor as Part of Professional Development}

The first research question is based on the importance attributed to the role of mentor as a means of enabling full integration of newly appointed academics into the professional community. This has been found to be particularly important issue for female academics as they experience gender differences during critical transition phases of their career. 
Two metacodes emerge in the narratives referring to mentors: those which refer to the subject of the mentoring and those which relate the experience of this relationship. Two issues emerge in the first analytical metacode: the identification of the mentor as a feminine or masculine figure and the absence of mentoring.

The code 1.1 Identification of mentor refers to the segments of the female academics' narratives that identify the presence of a mentor, whether this figure is a thesis director, department colleague or another person. The subcode 1.1.1 Male has a higher frequency. Female academics identify as mentors the directors of their thesis, research projects, and professors in their field of research, their department heads or colleagues and, in some cases, their partners or family:

As regards my research, my mentor is also my husband. He recommends my bibliography, he recommends attitudes, [...] it's very useful to me, [the mentoring] of my husband. (Associate lecturer 001)

The subcode 1.1.1 Male, some of the narratives refer to a female mentor (subcode 1.1.2) as thesis director, professor etc.:

I also have mentors in the area of politics, in the moral field and also in the intellectual. (Associate lecturer 004)

Some participants consider that they do not have or have not had a mentor, and so consider themselves to be their own mentor for their career (subcode 1.1.2):

I have no mentor, unfortunately no, [...] I know people that have had, and it is enviable; yes, you are lucky to have a person to supervise your studies, your career, who looks after this, I haven't had this, what I would consider a mentor. (Associate lecturer 016)

Unfortunately, I haven't had a research group in which I could develop a line of research. (Associate lecturer 014)

I don't consider that I have had a mentor, my counselling has been my own experience and my guide my own desire for professional and personal progress. (Associate lecturer 006)

Looking into experiences of mentoring in more depth, codes 2.1 and 2.2 emerge from metacode 2 and these express, respectively, satisfaction or dissatisfaction with the mentor, basically as regards equality of treatment between male and female academics. The majority of narratives say they have never felt gender discrimination in their relations with their mentor:

Do I see a difference in the treatment of other colleagues? The truth is I don't, I think he is a person who is committed to the development of future academics or grant-holders or even just future professionals; he's a pretty open person and tries to support future professionals. (Associate lecturer 002)

However, some accounts reveal differences in treatment:

My mentor disappointed me. He told me clearly, without circumlocution, that if he had a man asking for promotion, although I had a very good CV, I had no chance. (Associate lecturer 015)

In short, about half the academics consider they have not had the opportunity to enjoy having a mentor. Men have for the most part been mentors. It is evident in the results that the mentor figure as support as well as a role model is not a very important presence and that the number of female mentors is an insignificant proportion of the total. It is appropriate to remember here that among the reasons for women's disaffection and indifference towards science, the lack of role models that allow women to see themselves represented - or to imagine themselves - as scientists.

\subsection{Second Research Question: Differences in Opportunities in Academia Due to Gender}

Three categories have emerged from this question. The first, code 3.1, refers to the perception of gender differences in professional opportunities. In this code the participants said clearly that they had not perceived any differences. The second code, 3.2, specifies the differentials around four areas of academic opportunity - training, promotion, integration and promoted posts. The third code, 3.3, identifies the experiences of the participants as regards their interactions and relationships in the department or investigation unit where they work.

The participants, who in code 3.3 say they have not perceived any gender differentials, often highlight the satisfaction they get from teaching or researching networks. However, it is important to emphasise that these accounts come from participants working in centres with a greater ratio of female academics that in the university are the faculties of Education and Nursing.

Relationships, both personal and professional, have always been good; in fact we have always formed a good team and always worked together. (Associate lecturer 011)

We continue with this attitude, we tell each other what exercises we do in class, we ask for criticism from colleagues; we go to other teacher's classes to see what we can do, or what we can change. (Associate lecturer 001) 
As regards the question of no perception of gender differentials in opportunities, another complementary coding was carried out for the perception or lack of perception of discrimination in the institution. The results obtained show that top women do not like to see themselves as victims and do not look for blame regarding discrimination

Code 3.1 compares the narratives which express a perception of gender differentials in professional opportunities in the four areas of differentiation: in training, promotion, department integration and distribution of responsibilities. Some differences in opportunity emerged:

The university is very class conscious, you are an Associate lecturer, you don't have a PhD, but aren't you a Senior lecturer? (Associate lecturer 009)

Other differentials I have seen are cases of personal favouritism towards some people. (Associate lecturer 004)

We now focus on the differentials, which affect the areas of promotion and the taking on of responsibilities as these have been seen to show greater differences (subcode 3.1.2 'Differentials in promotion'). The promotion of one person rather than another may depend on relational links. The extent to which the matter of gender has had an influence is described in the following extracts:

The head of department used to promote men before women. (Associate lecturer 002)

We have been in some tribunals or some places and I have seen differences in the way people are treated just for being a man or a woman, and then I have argument in favour of equality. (Associate lecturer 005)

Subcode 3.1.4 reveals a viewpoint that is not very strong as regards the perception of differentials in opportunities to hold positions of responsibility. We have included those narrative fragments that identify differences in access to posts involving coordination, for example the coordination of subjects, the coordination of areas, etc. Although the figures reveal that few women currently hold such positions of responsibility, the women teachers' narratives insist that there are no differences in the distribution of responsibilities, with the exception of a minority who specifically state inequalities:

I have perceived differences, in the distribution of responsibilities; they give women the undergraduate teaching and the men the graduate teaching. (Associate lecturer 011)

\subsection{Third Research Question: Perception of Relations Between Colleagues}

The third question is related to metacode 4 about gender differentials. It is configured around the different types of relations perceived in departments and subdivided into four codes related to the experiences of the participants as regards their relations with colleagues: 4.1 Collaborative; 4.2 Affected by gender.

The code that is the most worrying for female academics, perhaps caused by their initial professional motivation, is the one centred on the lack of peer and departmental cooperation (code 4.1):

My joining the university was because I liked the possibility of sharing knowledge. (Associate lecturer 005)

Professional relations are difficult to establish because men have an insular way of working. (Associate lecturer 004)

The code 4.2 relations Affected by gender refers to those personal and professional relations in which there is dissatisfaction due to male discriminatory attitudes:

Regrettably, in this society there are common stereotypes [...] this vision of a woman, from my experience, as, well, blonde, and so on. (Associate lecturer 008)

It is a male-dominated institution where male behaviour is rewarded more [...] (Associate lecturer 007)

There are jokes which are a bit male chauvinistic that I don't share [...] there is a kind of masculine chit chat that I don't want. (Associate lecturer 011)

Female academics also describe the defence of their rights in these situations:

Yes, I usually defend my rights when I see gender differences, I've defended them and this has definitely brought me problems and difficulties. (Associate lecturer 005)

I don't feel any discrimination but maybe they would pay me more attention, if I were a man. (Associate lecturer 009)

\section{Discussion}

The results of this research give us a deeper understanding of academic women's ambiguous perspectives on their opportunities and integration as a minority group in the academy. As regards the first question, we can state that a relevant number of participants do not have or have not had a mentor. A large number have or have had a male 
mentor. On the whole, the data show that, although there has been a significant incorporation of academic women in recent years (Leeman, 2002; Raddon, 2002), academic women still find it difficult to benefit from networks and mentoring. Perhaps a paternalist and patriarchal vision still survives in academia (Winchester, \& Browning, 2015). Kurtz-Costes, Helmke and Ulku-Steiner (2006) point out the necessity for mentors to act as role models. Given that in general in all countries there are few female academics in top posts, it is difficult to find feminine role models at university (Acker \& Wagner, 2017). For this reason, it may be advisable to substitute the individual mentoring model for a collaborative team model in which there is a mix of gender. Acker and Armeti (2004) propose the support of female colleagues, personal tutoring, and group integration in order to 'break the silence'.

In answer to the second research question, the participants do not consider there to be clear differences in opportunities in general, except in promotion opportunities. Here, more than a half of the narratives allude to gender discrimination. And, although all the participants do not blame the institution for the differentials in promotion, they believe that progress can be made more difficult, in part, for personal and family reasons, as they have to assume motherhood and domestic tasks (Gallardo, 2021), thus reducing time devoted to their career (Ahmad, 2017).

Academic women often fail to perceive the everyday, subtle and frequent inequalities that gradually cause a decline in opportunities for insertion into communities formed by the initiated (Maher \& Tetreault, 2011). Acker and Dillabough (2007) explain how, in the same way, female academics are vulnerable to symbolic domination in the culture of the work place. The great majority of academic women in this study, however, show little disposition to explore critically the relationship between gender and power. It seems, then that the participants tend to have a more insecure attitude towards their own strengths. They tend to show a more modest attitude as regards their personal merits and values than their male colleagues.

In answer to the third research question, the narratives reveal a desire for more collaboration and coordination in the work place. It is clear that more participants say they consider relations in the departments to be cordial, only $10.08 \%$ state explicitly that there is good departmental coordination. As regards the degree of integration in a work team, a minority only perceived a significant integration. There also seem to be cases of asymmetry in treatment and attention.

If we consider that a successful academic life is a complex concept that need conjugate the career advancement with an excellent professional development as teachers (Subbaye \& Vithal, 2017), researchers and managers, it is necessary that the collaborative opportunities to do it reach all members. And we must revise the institutional politics because, could be, the professional development culture is not impregnating the university fabric as must do it.

\section{Conclusion}

The authentic professionalization of women will not come about with simplistic, easy solutions but in the words of Walkerdine, Lucey and Melody (2001, p. 182) "through the painful struggle of constant reinvention". There should be more self-reflection and self-criticism by women in their search for the recognition and increased visibility of academic women. This will only be possible through a change in personal attitudes, not only by male academics but also by many female academics that accept a system that benefits neither them nor the university community as a whole. The findings from this study have shown that participants are not self-complacent. However, although some demand more responsibilities and interaction as the way to increase authentic academic identity for all, there is some ambiguity and evidence of silence among those women who hold senior positions in the university. We have found that the great majority of female academics show little disposition to explore critically the relationship between gender and power. In this respect, some of the participants promise firm personal resolutions. Aware that talent and effort is what really counts, they claim equal opportunities.

The narratives of the participants, even in their restrained and moderate comments (Broido, Brown, Stygles \& Bronkema, 2015), allow us to confirm that universities are a faithful reflection of the inequalities in social contexts and in cultural practices. Consequently, universities, departments and investigation units must make a concerted effort to create a more participative and collaborative culture which could encourage more authentic professional development for all members (Day \& Sachs, 2004).

Finally, we would stress the urgency of set up at the universities authentic and strong models for professional development that offer to all academics, as much women as men, the opportunities that they need. Such a model would see the teacher integrated in the work community in which they are situated engaging with the critical through the collaborative (Cochran-Smith \& Lytle, 2009); and, above all, a model of equity in which the gender, race and culture differentials, and in short, the power differentials would be abolished in the widening of the opportunities (Ladson-Billings, 2005, 2009). 
We would like to end by expressing our heartfelt and sincere gratitude to all the academic women who have voluntarily and generously participated in this study. Since one of the premises of qualitative research is the relevance of interpersonal relations in the research process rather than the mere examination of objects under study, we would like to assure these academic women that their voices have been a great encouragement in our intention to continue this line of research into the gender gap in Higher Education.

\section{References}

Acker, S., \& Armenti, C. (2004). Sleepless in academia. Gender and Education, 16(1), 3-24.

Acker, S., \& Dillabough, J. A. (2007). Women 'learning to labour' in the 'male emporium': exploring gendered work in teacher education. Gender and Education, 19(3), 297-316.

Acker, S., \& Wagner, A. (2017). Feminist scholars working around the neoliberal university. Gender and Education. https://doi.org/10.1080/09540253.2017.1296117

Ahmad, S. (2017). Family or future in academy?. Review of Educational Research, 87(1), 204-239.

Aiston, S. J., \& Fo, C. K. (2020). The silence/ing of academic women. Gender and Education. https://doi.org/10.1080/09540253.2020.1716955

Aiston, S. J., \& Jung, J. (2015). Women academics and research productivity: an international comparison. Gender and Education, 27(3), 205-220.

Anderson, J., Goodall, H., \& Trahar, S. (2020). Women in powerful conversation: collaborative autoethnography and academia. International Journal of Qualitative Studies in Education, 33(4), 393-403. https://doi.org/10.1080/09518398.2019.1671632

Bagilhole, B., \& Goode, J. (2001). The contradiction of the myth of individual merit, and the reality of a patriarchal support system in academic careers: a feminist investigation. European Journal of Women's Studies, 8(2), 161-180.

Barnard, S., Rose, A., Dainty, A., \& Hassan, T. (2021). Understanding social constructions of becoming an academic through women's collective career narratives. Journal of Further and Higher Education. https://doi.org/10.1080/0309877X.2020.1865523

Blickenstaff, J. C. (2005). Women and science careers: leaky pipeline or gender filter?. Gender and Education, 17(4), 369-386.

Bosanquet, A., Mailey, A., Matthews, K. E., \& Lodge, J. M. (2017). Redefining 'Early Career' in Academia: A Collective Narrative Approach. Higher Education Research and Development, 36(5), 890-902. https://doi.org/10.1080/07294360.2016.1263934

Bourdieu, P. (2000). Les structures sociales de l'économie. Paris: Seuil.

Boylan, M., Coldwell, M., Maxwell, B., \& Jordan, J. (2018). Rethinking models of professional learning as tools: a conceptual analysis to inform research and practice. Professional Development in Education, 44(1), 120-139. https://doi.org/10.1080/19415257.2017.1306789

Brabazon, T., \& Schulz, S. (2020). Braving the bull: women, mentoring and leadership in higher education. Gender and Education, 32(7), 873-890. https://doi.org/10.1080/09540253.2018.1544362

Broido, E. M., Brown, K. R., Stygles, K. N., \& Bronkema, R. H. (2015). Responding to gendered dynamics: Experiences of women working over 25 years at one university. The Journal of Higher Education, 86(4), 595-627. https://doi.org/10.1080/00221546.2015.11777376

Cammack, J. C., \& Kalmbach-Phillips, D. (2002). Discourses and subjectivities of the gendered teacher. Gender and Education, 14(2), 123-133.

Clandinin, J. D. (2013). Engaging in narrative inquiry. New York: Routledge.

Clandinin, J. D., \& Husu, J. (2017). The SAGE handbook of research on teacher education. New York: Sage.

Cochran-Smith, M., \& Lytle, S. (2009). Inquiry as stance: Practitioner research for the next generation. New York: Teachers College Press.

Cochran-Smtih, M., \& Villegas, A. M. (2015). Studying teacher preparation: the questions that drive research. European Educational Research Journal, 14(5), 379-394.

Danowitz-Sagaria, M. A. (2007). Women, universities, and change: gender equality in the European Union and the United States (Issues in Higher Education). New York and London: Palgrave Macmillan. 
Dapiton, E. P., Quiambao, D. T., \& Canlas, R. B. (2020). Parenting as a moderating factor for research productivity and work-life balance: evidence from Philippine women academics. European Journal of Educational Research, 9(4), 1425-1434. https://doi.org/10.12973/eu-jer.9.4.1425

Darling-Hammond, L. (2017). Teacher education around the world: What can we learn from international practice?. European Journal of Teacher Education, 40(3), 291-309.

Day, C. (1993). Reflection: a necessary but not sufficient condition for professional development. British Educational Research Journal, 19, 83-93.

Day, C., \& Sachs, J. (2004). Professionalism, performativity and empowerment: discourses in the politics, policies and purposes of continuing professional development. In C. Day, \& J. Sachs (Eds.), International handbook on the continuing professional development of teachers (pp. 3-32). Milton Keynes: Open University Press.

Denzin, N. K., \& Lincoln, Y. (2000). Handbook of qualitative research. London: Sage Publicacions, Inc.

Desimone, L. M., \& Pak, K. (2017). Instructional coaching as high-quality professional development. Theory Into Practice, 56(1), 3-12.

Erixon-Arreman, I., \& Weiner, G. (2007). Gender, research and change in teacher education: a Swedish dimension. Gender and Education, 19(3), 317-337.

European Commission. (2016). She Figures 2015. Luxembourg: Publications Office of the European Union.

Eurostat Statistics Explained. (2017). Tertiary education statistics. Retrieved from http://ec.europa.eu/eurostat/statisticsexplained/index.php/Tertiary_education_statistics\#Further_Eurostat_in formation

FECYT. (2017). Cientificas en cifras 2017. Scientific Figures 2017. Retrieved from https://www.ciencia.gob.es/stfls/MICINN/Ministerio/FICHEROS/UMYC/Cientificas_cifras_2017.pdf

Flores, M. A., \& Day, C. (2006). Contexts which shape and reshape new teachers' identities: A multi-perspective study. Teaching and Teacher Education, 22, 219-232.

Gallardo, M. (2021). Does maternity affect women's careers? Perceptions of working mothers in academia. Educación XX1, 24(1), 405-428. Retrieved from http://orcid.org/10.5944/educXX1.26714

Goodson, I., Antikainen, A., Sikes, P., \& Andrews, M. (2017). The Rutledge international handbook on narrative and life history. New York: Routledge.

Gore, J., \& Rosser, B. (2020). Beyond content-focused professional development: powerful professional learning through genuine learning communities across grades and subjects. Professional Development in Education. https://doi.org/10.1080/19415257.2020.1725904

Huber, G. L., \& Gürtler, L. (2012). AQUAD 7. Manual del programa para analizar datos cualitativos (1. ed. 2003, Tübingen: Ingeborg Huber Verlag). Tübingen: Günter Huber.

INEBASE. (2020). Instituto Nacional de Estadística [Statistics National Institute]. Retrieved from http://www.ine.es/inebmenu/indice.htm

ISI-Thomson Scientific. (2008). Retrieved from http://www.thomson.com

Jones, K., \& O’Brien, J. (2011). Professional development in teacher education: European perspectives. Professional Development in Teacher Education, 37(5).

King, M. M., Bergstrom, C. T., Correll, S. J., Jacquet, J., \& West, J. D. (2017). Men set their own cites high: Gender and self-citation across fields and over time. Socius, 3, 2378023117738903.

Knights, D., \& Richards, W. (2003). Sex Discrimination in UK Academia. Gender, Work and Organization, 10(2), 213-238.

Krefting, L. A. (2003). Intertwined discourses of merit and gender: evidence from academic employment in USA. Gender, Work and Organization, 10(2), 260-278.

Kurtz-Costes, B., Helmke, L. A., \& Ulku-Steiner, B. (2006). Gender and doctoral studies: the perceptions of Ph.D. students in an American university. Gender and Education, 18(2), 137-155.

Ladson-Billings, G. (2005). Beyond the big house: African American educators on teacher education. New York: Teacher College Press.

Ladson-Billings, G. (2009). The dreamkeepers: successful teachers of African American children. San Francisco, Calif.: Jossey-Bass Publishers.

Lave, J., \& Wenger, E. (1991). Situated learning: Legitimate peripheral participation. New York: Cambridge University Press. 
Ledwith, S., \& Manfredi, S. (2000). Balancing gender in higher education: a study of the experience of senior women in a 'New' UK university. European Journal of Women's Studies, 7(1), 7-33.

Leeman, R. J. (2002). Transitions into research careers in Switzerland. Education and Training, 44, 146-198.

Lieberman, A., \& Pointer-Mace, D. H. (2008). Teacher Learning: the key to Educational Reform. Journal of Teacher Education, 59(3), 226-234.

Maher, F., \& Tetreault, M. K. (2011). Long-term transformations: excavating privileges and diversity in the academy. Gender and Education, 23(3), 281-297.

Massachusetts Institute of Technology. (1999). A study on the status of women faculty in science at MIT. Retrieved from http://web.mit.edu/fnl/women/women.html\#The\%20Study

Miles, M. B., Huberman, A. M., \& Saldaña, J. (2014). Qualitative data analysis: A methods sourcebook (3rd ed.). Thousand Oaks, CA: Sage.

NAP-The National Academies Press. (2009). Gender Differences at Critical Transitions in the Careers of Science, Engineering and Mathematics Faculty. Committee on Gender Differences in the Careers of Science, Engineering, and Mathematics Faculty; Committee on Women in Science, Engineering, and Medicine; Committee on National Statistics; National Research Council.

Raddon, A. (2002). Mothers in the academy: positioned and positioning within discourses of the 'successful academic' and the 'good mother'. Studies in Higher Education, 27(4), 387-396.

Raduan, N. A., \& Na, S. (2020). An integrative review of the models for teacher expertise and career development. European Journal of Teacher Education, 43(3), 428-451. https://doi.org/10.1080/02619768.2020.1728740

Santos, J. M., Horta, H., \& Amâncio, L. (2020). Research agendas of female and male academics: a new perspective on gender disparities in academia. Gender and Education. https://doi.org/10.1080/09540253.2020.1792844

Scharber, C., Pazurek, A., \& Ouyang, F. (2017). Illuminating the (in) visibility of female scholars: a gendered analysis of publishing rates within educational technology journals from 2004 to 2015. Gender and Education, 1-29. https://doi.org/10.1080/09540253.2017.1290219

Subbaye, R., \& Vithal, R. (2017). Gender, teaching and academic promotions in higher education. Gender and Education, 29(7), 926-951. https://doi.org/10.1080/09540253.2016.1184237

Walkerdine, V., Lucey, H., \& Melody, J. (2001). Growing up girl: psychosocial explorations of gender and class. Basingstoke: Palgrave.

Whitcomb, J., Borko, H., \& Liston, D. (2009). Growing talent, promising professional development models and practices. Journal of Teacher Education, 60(3), 207-212.

Wieczorek-Szymańska, A. (2020). Gender Diversity in Academic Sector-Case Study. Adm. Sci., 10(3), 41. https://doi.org/10.3390/admsci10030041

Winchester, H. P. M., \& Browning, L. (2015). Gender equality in academia: a critical reflection. Journal of Higher Education Policy and Management, 37(3), 269-281. https://doi.org/10.1080/1360080X.2015.1034427

Wingood, G., \& DiClemente, R. (2002). The theory of gender and power. In R. J. DiClemente, R. A. Crosby, \& M. C. Kegler (Eds.), Emerging theories in health promotion practice and research: strategies for improving public health (pp. 313-345). San Francisco: Jossey-Bass.

\section{Copyrights}

Copyright for this article is retained by the author(s), with first publication rights granted to the journal.

This is an open-access article distributed under the terms and conditions of the Creative Commons Attribution license (http://creativecommons.org/licenses/by/4.0/). 